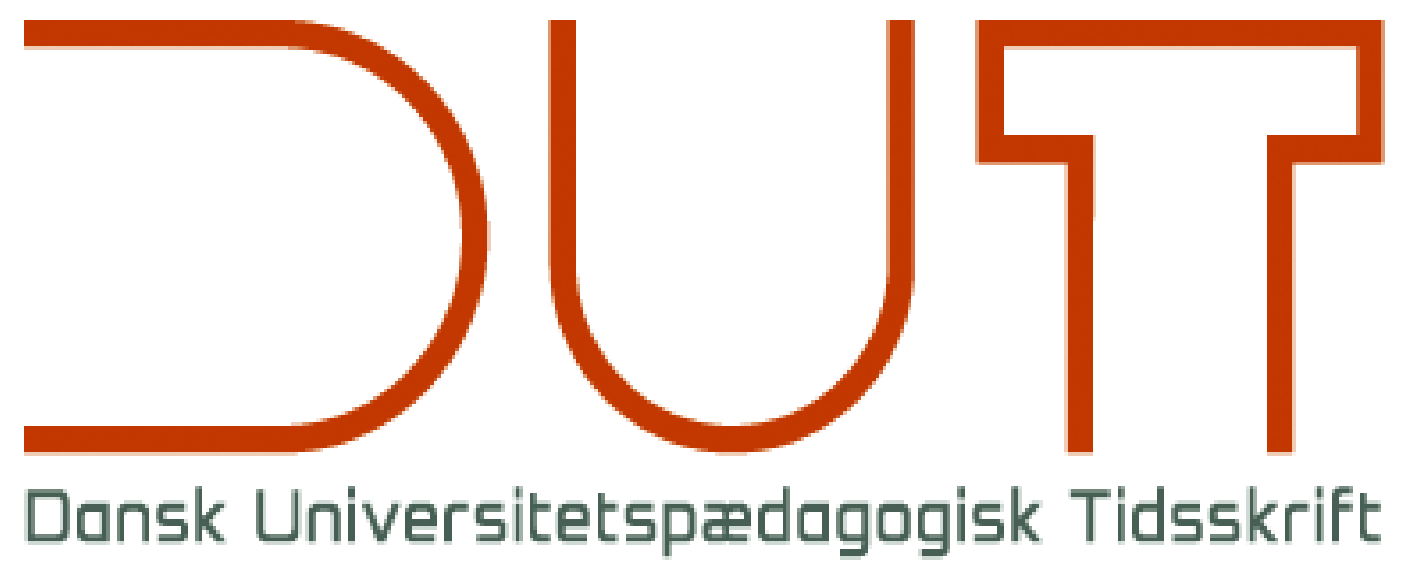

Universitetspædagogikum

Årgang 13 nr. 25 / 2018

Titel

Forfattere

Sidetal

Udgivet af

URL

Betingelser for brug af denne artikel

(C) Copyright
Dansk Universitetspædagogisk Netværk, DUN

$>$ http://dun-net.dk/

Brugbar peer feedback: Instruktion og træning, før de studerende selv skal give og modtage

Helle Hvass og Stine Heger

$59-70$

retp.//dun-net.dk/

Denne artikel er omfattet af ophavsretsloven, og der må citeres fra den. Følgende betingelser skal dog være opfyldt:

- Citatet skal være i overensstemmelse med "god skik"

- Der må kun citeres „i det omfang, som betinges af formålet“

- Ophavsmanden til teksten skal krediteres, og kilden skal angives ift. ovenstående bibliografiske oplysninger.

DUT og artiklens forfatter 


\section{Brugbar peer feedback: Instruktion og træning, før de studerende selv skal give og modtage}

Helle Hvass, cand.mag., udviklingskonsulent, Center for Undervisningsudvikling og Digitale Medier, Aarhus Universitet

Stine Heger, cand.mag., udviklingskonsulent, Center for Undervisningsudvikling og Digitale Medier, Aarhus Universitet

\section{Faglig artikel, fagfællebedømt}

Peer feedback er i dag en loeringsaktivitet på de fleste danske universiteter og ikke uden grund. For både den, der giver, og den, der modtager, laerer noget af at arbejde med peer feedback. Men studerende skal undervises i at give og modtage brugbar peer feedback. Det viser forfatternes erfaring med at instruere og traene studerende i tekstfeedback. I denne artikel proesenteres tre indsatser til at få peer feedback til at fungere: 1) Skab faste og trygge rammer, 2) Undervis i principper for brugbar peer feedback, 3) Instruér forbilledligt i feedback ved hjoelp af teksteksempel. Formålet er at give undervisere indsigt $i$, hvilken form for rammescetning og instruktion der er behov for, hvis peer feedback skal fungere som loeringsaktivitet $\mathrm{i}$ forbindelse med akademisk skrivning.

\section{Indledning}

Peer feedback er blevet populær på universiteterne, og det er der flere grunde til. For det første er der de læringspotentialer, som er forbundet med, at studerende ikke bare skal modtage feedback, men også selv skal give den. Arbejdet med peer feedback kan bl.a. medføre dybere forståelse af indholdet i undervisningen og øget refleksion over de krav og kriterier, der er i fagene (Nicol, Thomson \& Breslin, 2014). For det andet har universiteterne i dag fokus på output - altså på, at de studerende skal kunne anvende det, de lærer. Studerende skal ikke være passive modtagere af input, de skal være medskabere af undervisning og læring (Felten, 2014), og her er peer feedback central, fordi den skaber rum for, at studerende kan lære af hinanden. En tredje og mere praktisk grund er, at universiteterne er pressede af, at der er mange studerende og få ressourcer til, at underviserne kan give feedback - et problem, som peer feedback delvis kan være med til at løse.

I denne artikel fokuserer vi på peer feedback på tekster som middel til, at studerende kan udvikle sig som opgaveskrivere. Feedback er en vigtig forudsætning for, at studerende kan udvikle deres skriftlige akademiske færdigheder, og studerende kan rent faktisk hjælpe hinanden med at udvikle disse færdigheder via peer feedback. 
Men man kan ikke uden videre slippe studerende løs og sætte dem til at give hinanden feedback - og opstilling af faste feedbackkriterier (rubrics) er ikke tilstrækkelig hjælp. Det erfarer vi som skrivevejledere i Center for Undervisningsudvikling og Digitale Medier på ARTS, Aarhus Universitet. Mange af vores studerende mangler træning i at give og modtage feedback, og den manglende træning kan stå i vejen for læringspotentialet ved peer feedback. I bedste mening sætter mange uddannelser tid af til peer feedback i undervisningsplanen, men denne tid skal studerende lære at bruge effektivt og professionelt, og det skal de lære af en forbilledlig instruktør. Én, som viser dem, hvordan man giver og modtager feedback, og som sørger for, at de får træning, før de skal klare sig selv. Så udover at de studerende skal opleve at have behov for den feedback, de modtager (motive), modtage den på et tidspunkt, hvor de har brug for den (oppurtunity), og være villige til at indarbejde den (means) (Shute, 2008) skal de altså også lære, hvordan de skal give den.

Det faglige ståsted for denne artikel er retorikken, som er en empirisk og normativ videnskab om produktion og reception af ytringer i deres helhed (Kock, 1997). Som skrivevejledere tager vi udgangspunkt i retorikkens didaktiske tradition for at undervise i skriftlig (og mundtlig) fremstilling ved netop at fokusere på både produktion og reception af ytringer. Rationalet er, at man bliver god til at skrive 1) af at producere skriftlige ytringer og modtage andres kritik til dem, og 2) af at læse andres skriftlige ytringer og give kritik til dem. Desuden tager vi udgangspunkt i den procesorienterede skrivepædagogik, som vandt frem i 70'rne i USA og gjorde op med skriveundervisning med et ensidigt fokus på det færdige produkt og bedømmelsen af det. Interessen var nu også på, hvordan tekster bliver til i en skriveproces, hvilke udfordringer utrænede skribenter møder, hvilken form for vejledning skribenter har brug for m.m. I den forbindelse blev feedback helt central, fordi skribenterne ikke kun skulle have en reaktion på deres færdige tekster, men også skulle have reaktioner på deres ufærdige tekster i proces.

\section{Vores praksis med facilitering af peer feedback}

Viden om studerendes kompetencer inden for peer feedback har vi fra et projekt om vejledningsformer. I dette projekt har vi udviklet vejledningsformen skrivegruppefacilitering. Skrivegruppefacilitering er et ekstracurriculært tilbud til kandidatstuderende, som ønsker at mødes i en skrivegruppe flere gange over en periode for at udvikle deres skrivekompetencer sammen med andre studerende. Tilbuddet går ud på, at vi mødes med skrivegruppen i to timer, hvor vi dels giver instruktion i, hvordan gruppen kan arbejde med mundtlig peer feedback i forbindelse med opgaveskrivning, dels giver gruppen mulighed for at træne det at give og modtage feedback sammen med os. Det er især i forbindelse med træningen, at vi har observeret, hvad der udfordrer studerende ved peer feedback, og det er med udgangspunkt i disse udfor- 
dringer, at vi skriver denne artikel. Artiklen bygger på observationer fra ca. 40 skrivegruppefaciliteringer (ca. 200 studerende), og det er vores mål at gøre undervisere opmærksomme på, 1) hvad der kan stå i vejen for, at studerende kan blive gode til peer feedback, 2) hvad man skal huske, hvis man vil instruere og træne studerende i peer feedback.

\section{Fem forhindringer for, at peer feedback kan blive brugbar}

I vores praksis med skrivegruppefacilitering er vi blevet opmærksomme på, at vi ikke kan tage for givet, at vores studerende bare uden videre kan give og modtage peer feedback til tekster i proces. I skrivegruppefaciliteringen sørger vi derfor for at gøre de studerende bevidste om, hvad der kan stå i vejen for, at deres peer feedback kan blive brugbar.

Den første forhindring, som de studerende skal være bevidste om, er, at de er mere vant til at modtage feedback end til at give den. Når de så pludselig skal til at give feedback, kan de komme til at blive meget optagede af deres egen præstation som feedbackgivere. Her gælder det om at tøjle sit behov for at vise alt, hvad man kan få øje på i den andens tekst, som kunne forbedres. Intet tyder på, at den form for feedback hjælper nogen til at blive bedre til at skrive. Vi ved fra forskning i skriveprocesser, at den feedback, man modtager, styrer ens opmærksomhed (Sommers, 1982). Hvis man modtager al mulig feedback, der peger i alle mulige retninger, kan det med stor sandsynlighed medføre, at man opgiver at bruge den, fordi man ikke kan overskue, hvor man skal ende og begynde.

Den anden forhindring handler om, at man kan have tendens til at fokusere på kun at finde fejl i andres tekster. Derfor skal man vænne sig til at se mangler i en tekst som potentialer for udvikling, og det er ikke altid nemt, hvis man selv hovedsageligt har oplevet at få udpeget fejl i sine færdigskrevne tekster. Vi ved fra skrivepædagogikken, at brugbar feedback både skal pege på potentialer og give forbedringsforslag, og at det skal ske undervejs i skriveprocessen. Feedback skal med andre ord føre til, at skribenten får andres hjælp til at få øje på "what works, and what needs work" (Murray, 1968, s. 4). En del af vores studerende finder det meningsløst, at de også skal pege på det, der virker, i hinandens tekster. De er simpelthen helt uvante med at lede efter det, der fungerer godt, og vi oplever studerende, som siger, at det er spild af tid at fokusere på det. Derfor understreger vi, at man bliver god af at gå på jagt efter det gode, som det beskrives i retorikkens ældgamle praksis, imitatiolæsning (Kock, 2001). Imitatio-læsning går ud på, at man netop bliver god til at skrive af at læse og efterligne det, der virker $\mathrm{i}$ andres tekster. Og en skrivegruppe kan ligefrem udvikle et fælles forråd (copia) af gode indholdsaspekter og forbilledlige sproglige vendinger, når de læser hinandens tekster. Hvis man ikke aktivt beslutter sig for at give det positive opmærksomhed, ender man tit med at glemme det helt. 
Den tredje forhindring hænger sammen med det foregående: De fleste studerende er mere vant til at modtage summativ feedback, altså en bedømmelse af en færdig tekst, end til at modtage formativ feedback, som kan hjælpe dem til at videreudvikle deres ufærdige tekst. Det kan være nemt nok for studerende at forstå - i princippet - at de ikke skal bedømme en andens tekst, men udfordringen er: Hvad skal de så? Da forskellen på formativ og summativ feedback kan være svær at definere helt klart (Taras, 2009), introducerer vi den amerikanske skrivepædagog Peter Elbows to feedbackformer: den kriteriebaserede og den læserbaserede (Elbow, 1981). Den kriteriebaserede er de studerende ofte bekendte med, for den handler om at tage stilling til, hvorvidt en andens tekst lever op til på forhånd bestemte kriterier, fx for struktur og argumentation. Den læserbaserede feedbackform er de færreste bekendte med, og derfor er de forbeholdne over for den. Læserbaseret feedback går ud på, at man giver sin læseroplevelse videre og fx svarer på spørgsmål som: Hvor får jeg noget interessant at vide? Hvor bliver jeg forvirret over noget? Hvor har jeg brug for at noget bliver uddybet? Skal studerende udvikle sig som opgaveskrivere, er denne feedbackform helt afgørende. Men mange studerende bliver meget usikre i mødet med den: De bliver i tvivl om, hvordan man formidler en læseoplevelse på en god måde, eller de bliver bange for at give en feedback, som er forkert. Det, som de studerende skal gøres opmærksomme på i den forbindelse, er, at ansvaret for, om feedback skal bruges eller ej, ligger hos feedbackmodtageren. Som feedbackgiver er man kun forpligtet til at forberede sig grundigt, målrette sin feedback og gengive sin læseroplevelse.

Den fjerde forhindring handler om de problemer, som kan opstå, hvis man ikke skelner mellem ufærdig og færdig tekst. Mange af vores studerende er meget lidt bevidste om, hvad det vil sige at være i en skriveproces, og har den opfattelse, at en tekst ikke er en rigtig tekst, før den er fuldstændig færdig. Kladder og udkast har ingen værdi, og det er pinligt at vise dem til andre. Denne opfattelse er meget uheldig, når man skal arbejde med tekstfeedback, fordi netop andres feedback kan have den effekt, at man faktisk bliver i stand til at udvikle sine kladder og udkast til færdig tekst - uden alt for mange kriser og søvnløse nætter. Linda Flower, som har forsket i kognitive processer i forbindelse med skrivning, skelner mellem det, at vi skriver til os selv for overhovedet at forstå, hvad vi selv tænker, writer-based, og det, at vi skriver til en læser, reader-based: "Good writing ... is often the cognitively demanding transformation of the natural but private expressions of Writer-based thought into a structure and style adapted to the reader" (Flower, 1979, s. 20). Andres feedback kan i denne optik være lige det, studerende har brug for, når de ikke kan finde ud af, hvad de skal skrive, om de forklarer sig godt nok, hvordan de kan vise, at de også forstår et modsynspunkt osv. De studerende skal med andre ord overvinde en modvilje mod at vise deres ufærdige tekster til andre. Derfor er det nødvendigt at skabe 
tryghed i skrivegruppen, så de ikke behøver at være nervøse for at tabe ansigt eller blive nedgjort.

Den femte forhindring handler om at skelne mellem globale og lokale tekstkvaliteter. Man kan have tendens til at beskæftige sig med formuleringer, kommasætning og slåfejl (det lokale) i en tekst, som i virkeligheden har meget mere overordnede problematikker (det globale) som manglende fokus, haltende argumentation eller uklart formål. Det lokale er ganske enkelt lettere at få øje på. Men i skrivegruppen skal de studerende lære at skelne mellem brugbar feedback og korrekturlæsning. Hver ting til sin tid. Det er forståeligt, at nogle studerende kan have svært ved at se bort fra manglende kommentarer og fejl i kildehenvisninger. Men disse studerende skal blive opmærksomme på, at det er tilladt at sætte perfektionisten lidt på pause. Det er som regel spild af tid at rette stave- og kommafejl i en meget ufærdig tekst, som garanteret skal skrives om flere gange. Behovet hos skribenten er som regel at få skrivegruppens feedback til at skrive noget, der giver mening for flere end vedkommende selv.

\section{Den gode nyhed: Vejen til brugbar peer feedback er ikke lang}

Det er altså forskellige forhindringer for brugbar peer feedback. Men heldigvis kan studerende hurtigt blive dygtige feedbackgivere og -modtagere. Nedenfor beskriver vi, hvad vi arbejder med i en skrivegruppefacilitering, som har til formål at instruere studerende i principperne for brugbar feedback og at give dem mulighed for at træne peer feedback. En sådan facilitering tager to timer, hvorefter de studerende naturligvis træner videre på egen hånd i deres skrivegruppe.

Hvis man som underviser vil instruere og træne sine studerende, inden man slipper dem løs til peer feedback, anbefaler vi, at man gør tre indsatser:

\section{1) Skab faste og trygge rammer}

De fleste studerende har blandede erfaringer med feedback. Mange mener, at de ikke kan bruge andre studerendes feedback til ret meget, og de er ikke villige til at vise deres ufærdige tekster fulde af fejl frem til nogen. Det skal vi som undervisere tage alvorligt og tale højt om. De studerende skal forstå, at dårlige erfaringer med feedback sjældent er forbundet med medstuderendes manglende evner som feedbackgivere, men med dårlige eller manglende rammer for feedbacken. De studerende skal også forstå, at de selv skal gøre en aktiv indsats for at opbygge respekt og tillid i gruppen, og at underviseren ret autoritativt vil styre, præcis hvad de skal tale om, hvad de skal aftale, og hvordan de skal arbejde.

En skrivegruppe består i vores optik optimalt af 4 studerende, der fast arbejder sammen over en længere periode. Ved første møde i gruppen er det afgørende, at 
de får mulighed for at præsentere sig for hinanden, fx ved at de hver især på to minutter svarer på de samme spørgsmål efter tur:

- Hvad skal jeg skrive opgave om?

- Hvorfor vil jeg gerne skrive om det?

- Hvilke ambitioner har jeg?

- Hvad plejer at gå godt i mine skriveprocesser?

- Hvad plejer at være svært for mig?

- Hvilke erfaringer har jeg med feedback?

- Hvad vil jeg gerne have ud af at arbejde med feedback i gruppen?

Det er betydningsfuldt, at rammerne for samarbejdet fastsættes tydeligt af underviseren. Normalt er vi fortalere for at inddrage studerende i at sætte rammerne for vores undervisning, men når det gælder rammerne for peer feedback, så optræder vi bevidst meget styrende. Vi beder de studerende om at prøve nogle meget faste rammer af, og vi opfordrer dem til at tro på, at disse faste rammer er vigtige for, at samarbejdet kan blive forudsigeligt, professionelt og effektivt. Man er i en sårbar situation, når man modtager feedback på noget, man har skrevet. Derfor er det vigtigt med faste rammer (Pædagogisk Center Samfundsvidenskab, 2013). I sin omfattende undersøgelse af den eksisterende forskning i formativ feedback beskriver Valerie J. Shute det sådan: "The premise underlying most research conducted in this area is that good feedback can significantly improve learning processes and outcomes, if delivered correctly. Those three words - 'if delivered correctly' - constitute the crux of this review" (Shute, 2008, s. 154). Det er altså ikke bare vigtigt, hvad feedbacken skal handle om, men i høj grad også, hvordan den bliver leveret. Rammerne skal med andre ord ligge meget fast.

Vores studerende skal have etableret faste indbyrdes aftaler om:

- Hvor ofte de skal mødes, og vi anbefaler hver anden uge

- Hvor længe møderne skal vare, og vi anbefaler to timer

- Hvor meget tid de skal bruge på at forberede sig, og vi anbefaler to timer

- Hvor meget tekst de kan sende til hinanden, og vi anbefaler maks. tre sider

- Hvornår der er deadline for at sende teksterne til hinanden, og vi anbefaler min. 24 timer inden mødet

- Hvornår det er tilladt at hyggesnakke, og vi anbefaler enten før eller efter mødet i skrivegruppen 


\section{2) Undervis i principper for brugbar peer feedback}

Principper for brugbar feedback skal underviseren gennemgå grundigt. De studerende skal blive opmærksomme på, at de har opfattelser og fordomme, som kan stå i vejen for, at de kan få udbytte af at give og modtage peer feedback. Nogle af principperne kan virke banale, og som underviser kan man have lyst til at springe dem over, fordi man ikke vil tale ned til de studerende. Vores erfaring er dog, at studerende ikke har lært at arbejde systematisk med feedback, og at de har brug for, at vi som undervisere fastlægger klare og til tider nærmest indlysende regler for selve feedbacken. Muligvis synes de studerende også, at principperne lyder banale, men den holdning forsvinder som regel, når de skal træne i praksis.

Det har studerende brug for at få at vide, når de skal instrueres i feedback:

\section{Overordnede principper}

1. Du skal træne for at blive god til at give og modtage feedback. Som studerende skal I hjælpe hinanden med at blive bedre i grupperne, og derfor skal I altid huske også at give feedback til den feedback, I har modtaget, dvs. tale om, hvilken feedback der er mest brugbar.

2. Feedback skal altid forberedes hjemmefra, så den bliver målrettet og gennemtænkt.

3. I arbejder med ufærdige tekster - tekster, der er ved at blive til. Vis respekt ved altid at opføre jer anerkendende og konstruktivt.

\section{Når du giver feedback, skal du:}

1. Lede efter potentialer i teksten og prøve at komme med konkrete forslag til, hvad skribenten kunne gøre for at komme videre.

2. Prioritere din feedback. Feedbackmodtagere kan ikke håndtere alle mulige kommentarer i alle mulige retninger.

3. Være bevidst om globale og lokale tekstkvaliteter, og give feedback der passer til tekstens status: ufærdig, halvfærdig eller tæt på færdig.

4. Koncentrere din feedback om det globale før det lokale. Det globale har at gøre med: fokus, formål, genre, struktur, funktion af afsnit o.l. Det lokale har at gøre med formuleringer, ordvalg, stavning, kommatering o.l.

5. Begynde din feedback med at pege på noget, der fungerer godt. Fremhæv i det hele taget potentialer i teksten. Giv forbedringsforslag til det, der fungerer mindre godt, hvis du kan.

6. Huske at være konkret: Din feedback må ikke være intetsigende à la: "Jeg synes, at din tekst er spændende". Feedbacken skal have substans à la: "I linje 7 
- 13 på s. 3 skriver du ... det er interessant, fordi...". Peg på det, du kommenterer.

7. Stå ved din feedback. Lad dig ikke påvirke af, hvad de andre feedbackgivere siger - forskellige feedbackgivere må gerne være uenige. Feedbackmodtagere lærer af at opdage, at teksten bliver opfattet forskelligt af forskellige læsere. Det er måske tegn på, at noget skal præciseres.

8. Ikke stille spørgsmål til feedbackmodtageren, men i stedet fortælle, hvad du blev i tvivl om, da du læste teksten

9. Huske at du ikke er til eksamen i feedbackgivning. Det handler ikke om at vise, hvor dygtig du er til at finde alle mulige små og store potentialer i en tekst og komme med alverdens konstruktive forslag. Det handler om at hjælpe forfatteren med det, der er behov for p.t.

10. Ikke dømme, om en tekst er god eller dårlig; du skal hjælpe teksten videre. Det gør du bedst ved at gengive din læseroplevelse. Fx ved hjælp af sætninger som disse:

- "Jeg blev meget interesseret, da jeg læste om ..., fordi ..."

- "Jeg blev overbevist om ..., da jeg læste ..., fordi ..."

- "Jeg fik lige præcis de oplysninger, jeg havde brug for, i afsnit ..."

- "Jeg kan ikke forstå ..., fordi ..."

- "Jeg kunne tænke mig at få uddybet ..., fordi ..."

- "For mig var ... forvirrende, fordi ..."

- "For mig var det overflødigt at læse om ..., fordi"

- "Jeg blev pludselig ukoncentreret, fordi ..."

- " "Jeg opfattede det sådan, at det, teksten overordnet vil, er ..."

\section{Når du modtager feedback, skal du:}

1. Fortælle på forhånd, hvilken form for feedback du har brug for, fx i et følgebrev.

2. Have din tekst foran dig, lytte og tage noter.

3. Tie stille. Du skal ikke forklare eller forsvare dig, når du modtager feedback. I skal ikke diskutere eller komme til enighed.

4. Ikke dunke dig selv i hovedet, når du får en feedback, som på overfladen virker indlysende. Det er nemmere at hjælpe andres tekster videre end at hjælpe sin egen tekst videre. 
5. Tage ansvaret for din egen tekst. Du skal tage imod al den feedback, du kan få, men du er ikke forpligtet til at bruge den i din tekst.

6. Vente med at tage stilling til den feedback, du har fået, til efter mødet er slut, og du kan gå i gang med at omskrive din tekst.

7. Give feedback på feedbacken ved at sige tak og fortælle, hvilken del af feedbacken der var særlig brugbar for dig.

\section{3) Instruér forbilledligt i feedback ved hjælp af teksteksempel}

Det er ikke svært at forstå principper for feedback i teorien. Men for de fleste studerende er det vanskeligt at udføre principperne i praksis. Grundene til det har vi skitseret tidligere i artiklen. Få skelner fx bevidst mellem ufærdig og færdig tekst, når det gælder den helt konkrete peer feedback. De har svært ved at lade være med at bedømme, også selvom principperne for feedback dikterer noget andet. De er uerfarne feedbackgivere, som skal lære en feedbackpraksis, der ikke er naturlig for dem. Derfor må vi som undervisere opføre os forbilledligt. Vi skal ikke kun opstille kriterier for feedback, vi skal vise, præcis hvilken form for feedback, de skal arbejde med, hvordan den udføres, og hvordan man helt konkret skal formulere sig. I vores projekt har vi som nævnt arbejdet med mundtlig fremlæggelse af feedback til tekster, men pointerne i det følgende gælder principielt for levering af både skriftlig og mundtlig feedback. I skrivegruppefacilitering arbejder vi med det forbilledlige ved at bruge tid på, at de studerende læser et konkret teksteksempel, som er skrevet af en anonym studerende, som ikke er med i skrivegruppen. De studerende forbereder peer feedback til eksemplet og fremlægger deres feedback for gruppen. Undervejs når de fremlægger deres feedback, kommenterer vi dens brugbarhed og kommer med gode eksempler på, hvad man med fordel kunne sige i sin feedback, og hvordan man kunne levere det. For at illustrere det forbilledlige viser vi nedenfor et konkret teksteksempel, som vi ofte har anvendt, samt tilknyttede feedbackkommentarer. Eksemplet udmærker sig ved at være kort og meget ufærdigt, hvilket gør det særdeles egnet til træning i at give formativ feedback.

\section{Følgebrev til feedback:}

Koere Skrivegruppe

Jeg er gået i gang med at skrive min analyse, men et eller andet er helt galt. Hvad er det jeg prøver at få frem? Hvad er det jeg gør galt?

Hilsen Bolette

Tekst:

Under interviewet bliver Birthe i tvivl om, om hun giver sin datter for stort et ansvar ved ikke at tale med hende om seksualitet og porno. Jeg vil gerne have 
uddybet hvori hendes tvivl består. Jeg starter med at opsummerer hvad det er jeg hører hende sige for på den måde at åbne til de refleksioner Birthe har omkring det at tale om seksualitet med sin datter.

E:[] det virker som om der er en meget klar graense...hvor hun giver udtryk for hvad hun vil vaere med til...hvor du bare...altså du ville aldrig gå over den? Og så kommer der så nogen refleksioner over .."giver jeg hende nu for stort et ansvar"...[]

Af Birthes svar kan jeg høre at det er rigtigt beskrevet, i alt fald begynder hun at fortælle.

B ja...ja!...det tror jeg også...og så taenker jeg måske den dag hvor hun så får en kareste ikke? ..men der tænker jeg den dag kan det jo også vœre for sent kan man sige...der kan hun have nået og...rodet rundt inden...at der ville det...der ville det falde naturligt på en anden måde ikke?...og sige ..hvad skal du op til loegen..og...få kigget på noget pravention...hvor jeg toenker at det ville vore meget overskridende på en eller anden måde og sige det nu ikk'?...hvor det ikke er mit indtryk...at der er gang i noget med drenge...nej..[

Birthes tvivl handler om, om hun ville være for grænseoverskridende, hvis hun vælger at tale om seksualitet nu, hvor hun ikke har nogen fornemmelse, af at der overhovedet er gang i noget med drenge. Birthe indgår her nærmest i en forhandling med sig selv, om hvorvidt det er rigtigt at hun ikke taler med sin datter om seksualitet nu. Hun vipper således mellem at synes at hun burde sige noget, fordi hun giver sin datter for stort et ansvar. Over til at det ville være overskridende at gøre det nu. Hun ender med at beslutte at det ikke er nu, at det er noget med den rigtige timing. Det skal være relevant for den unge og det definerer hun som når hendes datter "har gang i noget med drenge".

Umiddelbart kan eksemplet afstedkomme feedback som: "Jeg forstår det overhovedet ikke", "det har ikke ret meget med en analyse at gøre" eller "du har ikke styr på nutids-r ". Men den form for feedback har Bolette ikke brug for. Hun ved udmærket godt, at noget er galt, så hun har brug for at få hjælp til at komme videre. Og man kan som underviser illustrere, hvordan det kan ske, ved fx at give denne type feedback:

- Jeg bliver interesseret, når jeg læser, at det handler om, hvilke refleksioner forældre egentlig har mht. unge og seksualitet. Det virker relevant, at nogen undersøger det på vores uddannelse.

- Jeg forstår det sådan, at du gerne vil i dybden med en tvivl eller et dilemma, som din interviewperson oplever. Men jeg kommer alligevel i tvivl, for jeg forstår ikke helt, hvad der er vigtigt i analysen. Jeg veksler mellem at tænke, at afsnittet handler om ansvar, om tvivl, om at være grænseoverskridende, om 
at forhandle med sig selv. Jeg kunne tænke mig, at du uddybede, hvad udtalelsen egentlig er et eksempel på.

- Jeg mangler oplysninger om, hvordan analysen skal hjælpe dig til at svare på problemformuleringen. Du kunne $f x$ indlede afsnittet ved at skrive noget $i$ retning af: "I denne analyse undersøger jeg $X$ ved at anvende begrebet $Y$ for at ..."

- Jeg kan se, at du er i gang med at skrive analyse, fordi du gengiver et citat, som du efterbehandler. Så langt så godt. Dog er din efterbehandling meget genfortællende. Så jeg savner, at du viser, hvordan du ved hjælp af begreber fra vores fag finder ud af noget i analysen, som ikke er til at få øje på for det blotte øje.

- For mig er det unødvendigt, at du gengiver, præcis hvad du selv sagde for at få Birthe til at tale. Jeg er interesseret i, hvad Birthe sagde, og i din analyse af det. Så jeg synes, at du bare kan slette E:[] ... ansvar ... []".

Der er ingen tvivl om, at Bolettes tekst er meget mangelfuld, og det taler vi selvfølgelig med skrivegruppen om. Der er ikke tale om, at en skrivegruppe skal være en roseklub. Bolettes tekst har alle mulige mangler, men skrivegruppens opgave er ikke at tale længe om dem. Skrivegruppen skal i stedet bruge tid på at formidle deres læseroplevelse og på at være konstruktiv, så Bolette kan komme i gang med at forbedre sin tekst. Det er med gennemgangen af teksteksemplet, at vores studerende forstår og oplever i praksis, hvorfor de skal beskæftige sig med de principper for feedback, som kan virke banale i teorien.

\section{Sammenfatning}

Vi er store fortalere for peer feedback som middel til, at studerende udvikler sig som opgaveskrivere, ikke mindst fordi vores studerende melder tilbage til os, at arbejdet $\mathrm{i}$ skrivegrupperne øger kvaliteten af deres opgaver og letter deres skriveprocesser. Vi er opmærksomme på, at vi som skrivevejledere har en særlig position, fordi vi mødes med studerende, som selv opsøger vores tilbud, og som er meget motiverede for at lære at give og modtage feedback. Vi oplever fx ikke problemer med, at feedback gives mundtligt, selvom vi er klar over, at forskning i feedback tyder på, at skriftlig feedback er mere effektiv (Shute, 2008). Vi har tid til at instruere og træne, og vi oplever, at den tid er givet godt ud - selv med vores meget motiverede studerende. På den baggrund er det vores anbefaling, at man sætter tid af til instruktion og træning, hvis man fx vil lade peer feedback være en aktivitet, som de studerende skal udføre selvstændigt uden for den egentlige undervisning for at dokumentere, at de er studieaktive. I den forbindelse kan undervisere formulere de kvalitetskriterier i rubrics, som de studerende skal give hinanden feedback ud fra. Men som det er fremgået, så er det vores erfaring, at det ikke er nok. Man kan ikke gå ud fra, at alle 
studerende ved, hvordan de skal arbejde med peer feedback. Derfor har vi her i artiklen opfordret til, at en forbilledlig underviser bruger tid på at skabe trygge og faste rammer for peer feedback, på at gennemgå principper for feedback, og på at vise de studerende ikke bare hvad feedbacken skal handle om, men også hvordan den helt konkret skal gives. Om det foregår i to sammenhængende timer eller i løbet af de første undervisningsgange $i$ et forløb er ikke afgørende. Det afgørende er, at man ikke går ud fra, at alle studerende pr. automatik kan finde ud af at give og modtage peer feedback.

\section{Referencer:}

Cook-Sather, A. Bovill, C., Felten, P. (2014). Engaging Students as Partners in Learning and Teaching: A Guide for Faculty. San Francisco: Jossey-Bass

Elbow, P. (1981). Writing with Power. New York: Oxford University Press.

Flower, L. (1979). Writer-Based Prose: A Cognitive Basis or Problems in Writing. College English, 41, 19 - 37.

Kock, C. (1997). Retorikkens identitet. Rhetorica Scandinavica 1, 10 - 19.

Kock, C. (2001). Imitatio: en bro mellem tekstlæsning og skriftlig fremstilling. Dansk, 2, 3-10.

Murray, D. (1968). A Writer Teaches Writing. Boston: Heinle \& Heinle Publishers

Nicol, D., Thomson, A., Breslin, C. (2014). Rethinking feedback practices in higher education: a peer review perspective. Assessment \& Evaluation in Higher Education, $39,(1), 102-122$

Pædagogisk Center Samfundsvidenskab (2013). Skrivegrupper - hvorfor og hvordan?

Lokaliseret 22.09.17 på: http://samf.ku.dk/pcs/pdf filer/Skrivegrupper 2013.pdf.

Shute, V. (2008). Focus on Formative Feedback. Review of Educational Research, 78, (1), $153-189$.

Sommers, N. (1982). Responding to Students' Writing. College Composition and Communication, 2, 148 - 156.

Taras, M. (2009). Summative assessment: the missing link for formative assessment. Journal of Further and Higher Education, 1, 57 - 69 